Historic, Archive Document

Do not assume content reflects current scientific knowledge, policies, or practices. 

A radio conversation betwocn Miss Ru.th Van Doman, Burcau of Home Iconomics and Mr. Wallace Kaddorly, Office of Information, broadcast Thursday, June 2, 1938, in the Departmont of Agriculture period of the National Farm and Homo Hour, by the National Broadcasting Company and a notwork of 93 associate radio stations.

$$
--000000--
$$

\section{WAIIACE KADDEPIY:}

And here we are on the second of trese rare days in Junc. And here comes Ruth Van Deman with what looks to me like two glasses of jelly - - Rare June jolly, Ruth?

RUTH VANT DEMAN:

No, Mrs. Ycatman was a littlo apologetic about sending these, because they aren't June jellies. They're quince and mint-flavored apple from last fall.

KADDERIY:

They look very, vory good to mo.

VAN DEMAN:

She hoped they might give you a littlo inspiration, as you talk about the art of jelly making.

\section{KADDERLY :}

As you talk.

VAIN DENAN:

You aren't going to di sappoint those ladies in Pennsylvania and Montana are you? They wrote they'd be listening today.

\section{KADDERLY:}

Disappoint a listener? Never - - if I can holp it. As a matter of fact, I got very much interested over at the Delaware Experiment Station tho other day, in what they're doing on fruit poctins.

VAN DEMAN:

Helping to take the guesswork out of jelly making.

\section{KADDERLY :}

So it scoms. That was it. And I lilre what Mrs. Yeatman and Miss Stienbarger say in their new bulletin, about science working out basic yet flexible rules for making jellies and preserves. A great improvement over the old rule-of-thumb ways.

VAIN DEIVIAN:

Iuck, as Great Aunt Julia called it - - - 
KADDERIY:

Ies, and whe was very lucky to get as good results as she did - - considering the chonical nako-up of jelly, as we know it not, sith its comoination of pectin, acid, and susar - - -

VAIT DEWAIT:

And in cxactly the right proportions. If they're to give that clcar, spariling, tondor, quivering quelity of porfect jelly - - -

\section{KADDERIY:}

And I understand you have to use the iruit at a certain stage to get the most pectin and enoush acid.

VAN DEMAN :

Yes, slightly on the under-ripe side. But ripe enough to have fine flavor and color. Sometimes it's a good plar to mix somo under-ripe with fully ripe fruit to get the best juice for jelly.

\section{KADDERIY:}

Or you can combine a pectin-rich fmit with one that has no pectin.

VANT DEMAN :

Very often done, yes. Or add a pectin extract - provided you don't put in so much that you overpower the flavor of the fresh fruit.

\section{KADDERIY:}

I'm glad to hear you say that. I never could see any point to raspberry jelly that didn't taste like raspberries.

VANT DEMAIT:

But you can get very delicious and "djfferent" flavors by combining fruits. Currants and raspberries, for instance. Or gooseberries and réd raspberries. Gooseberries have the acid raspberries sometimes lack. And the raspoerries have that beautiful ruby red color - - -

\section{KADDERIY :}

Ah, we're getting around to the art now - - -

VANT DEMANT:

But there's still more science to getting the pectin out of the fruit.

\section{KADDERIY :}

That's right. I romember an excellont table in the bulletin - - -

VANT DEMART:

You like your facts in tables?

\section{KADDERTI :}

Yes, they don't beat around the bush. In about two inches this ono lists the fruits for making jelly. And says how much water to use to a pound of fruit, and how long to boil it to get out the pectin - - 
VAN DEMAN:

And hor much sugar to use to cach cup of the fruit juice.

\section{KADDERLY:}

And isn't that just about the whole formula for making jelly?

VAN DEMAN:

It is for anybody who's made jolly before and knows the practical points. An experionecd jelly maker knows that you get the bost results if you don't try to mako too much jolly at a time. Six or 8 cups of fruit juicc with sugar in proportion makes about a dozen or 15 glasses of jelly. In a wide flat-bottonod kettle you can cook that amount quickly. You don't overcook the pectin and make it lose its jollying pover. And you don't "boil away" the fine fresh flavor and color of the fruit, and make the jelly strong-tastod and dark - - -

\section{KADDERIY:}

And to tell when jelly's done, Mrs. Yoatman still thinks the 2-drop test's tho bost.

VAIV DEMANT:

Wallace, you certainly have conned that jolly bulletin carefully. KADDERIY:

You gave me an assignment. I tried to do my best.

VAIT DEIIANT:

Thank you a lot for your help.

\section{KADDERIY:}

But there's lots more you might say about the art of jelly making.

\section{VAIT DELALT:}

I know. But we'll have to postpone that. "Art is long and tine is fleeting". And I want to leave you time to give our listeners the title of the new bulletin - - -

\section{KADDERLY:}

Very well. "Home-made Jellics, Jams, and Preserves". That's what it's called. And by the way, Ruth, please thank Mrs. Yoatman very much for this jolly.

VANT DEMAN:

I'll do that.

\section{KADDERIY:}

I'n going to try it at lunch. I'll judgo it by the score card for home-made jelly on the back of hor bulletin.

VAN DEMAAT: mind.

That will bo turning the tables on her. But I know that she won't 
KADDERLY:

And I hope you won't $^{\prime}$ mind if a great nany jelly nakers - experienced and othervise - write you for this latest publication on "Fone-made Jellies, Jans, and Preserves."

VAN DEHAIT:

Certainly not. That s what we printed it for.

KADDERI Y:

Well, thank you Ruth, We'll be seeing you next Thursday. - - -

(Repeat hor to order bulletin). 